\title{
PENGARUH PENDEKATAN PEMBELAJARAN SOCIOSCIENTIFIC ISSUES TERHADAP KEMAMPUAN BERPIKIR KREATIF PESERTA DIDIK
}

\author{
Widia Rahmawati , Jujun Ratnasari, Suhendar \\ Program Studi Pendidikan Biologi, Fakultas Keguruan dan Ilmu Pendidikan, Universitas Muhammadiyah Sukabumi \\ Jl. R. Syamsudin No. 50, Cikole, Kota Sukabumi, Jawa Barat, Indonesia \\ Email: widiarahma1406@gmail.com
}

\begin{abstract}
ABSTRAK
Tujuan dari penelitian ini yaitu untuk mengkaji pengaruh pendekatan pembelajaran Socioscientific Issues terhadap peningkatan kemampuan berpikir kreatif peserta didik. Pembelajaran dengan pendekatan Socioscintific Issues perlu dilatihakan karena tidak hanya mengembangkan kemampuan berpikir kreatif saja, tetapi juga kemampuan lainnya pun dapat dikembangkan seperti kemampuan berpikir kritis, kemampuan mengambil keputusan dan kemampun berargumentasi. Metode penelitian yang akan digunakan adalah kuasi eksperimen dengan desain Nonequivalent Control Group. Penelitian ini dilaksanakan di Sekolah menengah Pertama Negeri 6 Kota Sukabumi dengan populasi penelitian yaitu kelas VII (Tujuh). Teknik sampling yang digunakan adalah Purposing Sampling. Indikator berpikir kreatif yaitu kepekaan, berpikir lancar, berpikir luwes, berpikir asli dan berpikir memperinci. Hasil penelitian menunjukkan nilai rata-rata $\mathrm{N}$-gain kelas eksperimen sebesar 0,56 lebih tinggi dari kelas kontrol sebesar 0,44. Hasil uji z menunjukkan bahwa data yang dihasilkan sesuai dengan kriteria yaitu $z_{\text {hitung }}=3,177>z_{\text {tabel }}=1.998$ dengan tingkat kepercayaan $0,05(5 \%)$, artinya $\mathrm{H}_{0}$ ditolak dan $\mathrm{H}_{1}$ diterima, artinya pendekatan pembelajaran Socioscientific Issues berpengaruh terhadap kemampuan berpikir kreatif peserta didik pada materi pencemaran air. Adapun tanggapan dari peserta didik terhadap pendekatan pembelajran Socioscientific Issue memberikan tanggapan positif pada penerpan pendekatan pembelajaran Socioscientific Issues.
\end{abstract}

Kata Kunci : Berpikir Kreatif, Socioscientific Issues.

\section{ABSTRACT}

The purpose of this study is to examine the effect of Socioscientific Issues learning approach to improving students' creative thinking ability. Learning with the Socioscintific Issues approach needs to be trained because it not only develops creative thinking skills, but also other abilities can be developed such as critical thinking skills, decisionmaking and arguing ability. The research method that will be used is quasi experiment with Design Nonequivalent Control Group. This research was conducted at State Junior High School 6 Sukabumi with research population that is class VII (Seven). The sampling technique used is Purposing Sampling. Indicators of creative thinking that is sensitivity, thinking smoothly, thinking flexible, original thinking and thinking detailing. The results showed that the average value of $\mathrm{N}$-gain of the experimental class was 0.56 higher than the control class of 0.44 . The results of the $\mathrm{z}$ test show that the data produced in accordance with the criteria is zhitung $=3.177>$ ztabel $=1.998$ with a trust level of 0.05 (5\%), meaning $\mathrm{HO}$ is rejected and $\mathrm{H} 1$ accepted, it means that the Socioscientific Issues learning approach influences the creative thinking ability of learners water pollution material. The response of learners to the learning approach Socioscientific Issue gave a positive response on the approach of learning approaches Socioscientific Issues.

Keywords: Creative Thinking, Socioscientific Issues.

\section{PENDAHULUAN}

Sistem pendidikan merupakan salah satu aspek utama yang berperan penting dalam menghadapi tantangan masa depan. Indonesia menerapkan kurikulum 2013 untuk menunjang pembenahan dibidang pendidikan. Sesuai dengan Permendikbud No. 69 tahun 2013 tentang kerangka dasar dan struktur kurikulum SMP/MTs, kurikulum 2013 bertujuan untuk mempersiapkan manusia Indonesia agar memiliki kemampuan hidup sebagai pribadi dan warga negara yang beriman, produktif, inovatif dan afektif serta mampu berkontribusi pada kehidupan bermasyarakat, berbangsa dan bernegara. Dalam mewujudkan tujuan pendidikan yang tercantum dalam kurikulum tersebut, berdasarkan penjelasan Permendikbud No. 96 tahun 2013 tentang kerangka 
dasar dan struktur kurikulum SMP/MTs maka pola pengembangan proses kegiatan pembelajarannya pun harus berubah salah satunya perubahan pola pembelajaran dari teacher-center menjadi studentcenter serta perubahan pola pembelajaran pasif menjadi kreatif. Hal demikian dipandang sebagai proses, sebagai produk dan sebagai prosedur.

Pada masa yang modern ini menunjukan bahwa pengetahuan saja tidak cukup, harus dilengkapi dengan kemampuan berpikir kreatif-kritis (Partnership 1st Century Skill, 2002). Hal ini menunjukan bahwa peserta didik dituntut ntuk mengembangkan kemampuan berpikir kreatif dalam proses pembelajaran yang merupakan bagian dari hakikat IPA. Penggunaan pola pembelajaran dalam kurikulum 2013 yang menuntut peserta didik untuk kreatif dalam pembelajaran juga merupakan salah satu indikator pentingnya kemampuan berpikir kreatif ini dilatihkan dan dimiliki oleh peserta didik. Kemampuan berpikir kreatif akan memunculkan kreativitas sebagai hasilnya. Kreativitas adalah kemampuan seseorang untuk melahirkan sesuatu yang baru, baik berupa gagasan maupun karya nyata yang relatif berbeda dengan apa yang telah ada sebelumnya (Suparman \& Husen, D.N 2015).

Kemampuan berpikir kreatif sangat penting untuk dimiliki oleh peserta didik, merujuk pada Putra (2012) berpendapat bahwa kreativitas merupakan kegiatan yang didalamnya terdapat proses yang mendatangkan hasil yang sifatnya baru dan berguna. Baru dalam artian inovatif, belum ada sebelumnya, segar, menarik, aneh, mengejutkan dan berguna berarti lebih praktis, memepermudah, memperlancar mendorong, menembangkan, mendidik, memecahkan masalah, mengurangi hambatan, mengatasi kesulitan dan mendatangkan hasil lebih baik. Permasalahan tidak hanya terdapat dalam pelajaran saja namun dalam kehidupan sehari-hari banyak sekali permasalahan yang dihadapi oleh peserta didik. Berdasarkan hal tersebut peserta didik dituntut untuk memiliki kemampuan berpikir kreatif untuk dapat membuat sesuatu yang kreatif sebagai solusi untuk menghadapi suatu permasalahan.

Di dalam kelas guru belum maksimal dalam melatih dan membimbing peserta didik menuju arah berpikir kreatif. Guru menyampaikan materi pembelajaran dengan metode konvensional seperti ceramah, kemudian memberikan soal-soal tanpa adanya proses diskusi dan langkah-langkah saintifik, padahal kemampuan berpikir kreatif hendaknya harus dimiliki oleh peserta didik. Materi pembelajaran yang disajikan pun masih berasal dari buku saja, belum menyajikan materi-materi yang nyata yang terjadi dalam kehidupan peseta didik, sehingga esensi dari materi yang diajarkan belum dapat sepenuhnya diterapkan dalam kehidupan sehari-hari.

Solusi untuk mengatasi permasalahan di atas diperlukan pendekatan pembelajaran yang dapat mengembangkan keterampilan berpikir kreatif peserta didik di sekolah. Pendekatan pembelajaran Socioscientific Issues (SSI) diharapkan dapat mengembangakan kemapuan berpikir kreatif peserta didik. Dikemukakan oleh Zeidler yang menyatakan bahwa SSI yang merupakan pendekatan yang bertujuan untuk menstimulasi perkembangan intelektual, moral dan etika, serta kesadaran prihal hubungan sains dengan kehidupan sosial (Zeidler, et al., 2005). Melalui pendekatan pembelajaran ini peserta didik dapat dengan leluasa mengkonstruksi pengetahuannya secara mandiri yang dipasilitasi oleh guru. Selain kemampuan berpikir, peserta didik dapat juga mengembangkan nilai moral dan etika melalui pendekatan pembelajaran SSI ini seta integrasi terhadap konsep-konsep sains yang memiliki dampak pada kehidupan masyarakat. Adapun tujuan dari penelitian ini untuk mengkaji pengaruh pendekatan pembelajaran Socioscientific Issues terhadap peningkatan kemampuan berpikir kreatif peserta didik dengan mengetahui perbedaan kemampuan berpikir kreatif peserta didik di kelas eksperimen dengan peserta didik dikelas kontrol, kemudian untuk mengetahui Perbandingan Peningkatan Setiap Indikator Kemampuan Berpikir Kreatif antara pembelajaran menggunakan pendekatan pembelajaran Socioscientific Issues dengan Pembelajaran menggunakan Direct Instuction dan untuk mengetahui tanggapan yang diberikan peserta didik terhadap pendekatan pembelajaran SSI pada materi pencemaran air.

Tekin, et al. (2016) menyatakan bahwa isu-isu SSI yang lebih ditekankan berdasarkan survey tahun 2004-2014 SSIn turkey yaitu energi nuklir, masalah lingkungan, pemanasan global, terapi gen dan radio aktif. Berdasarkan hal diatas pada penelitian ini materi yang akan disampaikan tentang konsep pencemaran air dengan isu yang diangkat yaitu banjir. Pencemaran air merupakan isu yang saat ini dialami dampaknya oleh masyarakat global termasuk di Indonesia. Isu banjir ini sangat sesuai untuk digunakan karena melibatkan konsep-konsep biologi dan permasalahan di dalamnya. 


\section{METODE PENELITIAN}

Metode penelitian yang digunakan dalam penelitian ini yaitu kuasi eksperimen. Dimana dalam penelitian ini terdapat dua variabel, yakni variabel bebas dan variabel terikat dengan kelas kontrol dan kelas eksperimen. Veriabel bebas dalam penelitian ini yaitu Pendekatan pembelajaran Socioscientific Issues (SSI) yang mengadaptasi sintak dari Model Pembelajaran Problem Solving Learning dan variabel terikatnya yaitu Kemampuan Berpikir Kreatif. Dikatakan sebagai kuasi eksperimen karena kelas kontrol pada penelitian ini tidak dapat berfungsi sepenuhnya mengontrol variabel-variabel luar yang mempengaruhi pelaksanaan eksperimen. (Sugiyono, 2016).

Penelitian ini dilakukan di SMP NEGERI 6 Sukabumi pada tahun ajaran 2017/2018 selama 2 kali pertemuan. Populasi dalam penelitian ini yaitu seluruh siswa kelas VII semester 2 SMP Negeri 6 Kota Sukabumi tahun ajaran 2017/2018. Penelitian ini dilakukan pada 2 kelas yaitu kelas VII F semester 2 sebagai kelas Ekeperimen dan kelas VII E semester 2 sebagai kelas kontrol tahun ajaran 2017/2018. Teknik pengambilan sampel yang digunakan dalam penelitian ini yaitu purposive sampling (Sugiono, 2016).

Penelitian yang dilakukan terdiri dari lima tahap, yaitu tahap pra persiapan, tahap persiapan, tahap pelaksanaan, tahap analisis dan pengolahan data dan yang ke lima tahap penyelesaian. Instrumen yang digunakan dalam penelitian ini berupa soal tes kemampuan berpikir kreatif dan angket tanggapan peserta didik terhadap penerapan pendekatan pembelajaran SSI. Instrumen yang digunakan dibuat oleh peneliti, disesuaikan dengan indikator-indikator yang berkaitan dan kemudian diuji terlebih dahulu sebelum digunakan

\section{HASIL DAN PEMBAHASAN}

Penelitian yang dilakukan ini menghasilkan data berupa data kuantitatif. Data yang diperoleh dengan menggunakan tes kemampuan berpikir kreatif peserta didik serta hasil rekapitulasi angket respon peserta didik terhadap pendekapan pembelajaran Socioscientific Issus pada materi pencemaran Air. Peningkatan kemampuan berpikir kreatif peserta didik diperoleh dari hasil selisih antara skor posttest dan pretest pada kegiatan pembelajaran setiap kelas. Nilai maksimal yang digunakan untuk menilai kemampuan berpikir kreatif peserta didik yaitu 100. Berikut hasil rekapitulasi nilai tes keampuan berpikir kreatif pada masing-masing kelas.

Tabel 1. Rekapitulasi Hasil Nilai Tes Kemampuan Berpikir Kreatif

\begin{tabular}{l|c|c|c|c}
\hline \multicolumn{1}{c|}{ Kelas } & $\begin{array}{c}\text { Rata-rata } \\
\text { Pretest }\end{array}$ & $\begin{array}{c}\text { Rata-Rata } \\
\text { Posttest }\end{array}$ & $\begin{array}{c}\text { Rata-rata } \\
\text { N-gain }\end{array}$ & Kriteria \\
\hline Eksperimen & 40.6 & 74.94 & 0.56 & Sedang \\
\hline Kontrol & 39.58 & 66.66 & 0.44 & Sedang \\
\hline
\end{tabular}

Tabel 1 menunjukkan hasil rekapitulasi tes kemampuan berpikir kreatif peserta didik dengan adanya peningkatan kemampuan berpikir kreatif dan dapat diketahui bahwa pada kelas eksperimen dan kelas kontrol menunjukkan keampuan awal berpikir kreatif yang berbeda. Rata-rata nilai pretest kelas eksperimen yaitu 40,6 sedangkan rata-rata nilai pretest pada kelas kontrol yaitu 39,58. Namun, setelah melaksanakan proses kegiatan pembelajaran masingmasing kelas menunjukkan terjadinya peningkatan pada tes kemampuan perpikir kreatif. Hal ini dapat dilihat pada tabel 4.1 rata-rata nilai pretest kelas eksperimen yaitu 74,94 dan pada kelas kontrol ratarata nilai posttes yang dihasilkan yaitu 66,66. Perolehan rata-rata nilai pretest dan posttest masingmasing kelas dapat dilihat pada Gambar 1. 




\section{Gambar 1 Grafik Nilai Rata-Rata Pretest dan Posttest Kelas Eksperimen dan Kelas Kontrol.}

Tabel 1 Tidak hanya menunjukkan nilai ratarata pretest dan posttest saja, tetapi juga menunjukkan nilai rata-rata $\mathrm{N}$-gain pada kelas eksperimen dan kelas kontrol. Kelas eksperimen menujukkan nilai rata-rata $N$-gain sebesar 0,56 , sedangkan pada kelas eksperimen menunjukkan nilai rata-rata $\mathrm{N}$-gain sebesar 0,44 . Secara keseluruhan nilai rata-rata $\mathrm{N}$-gain kelas eksperimen menurut Hake (dalam Meltzer, 2002) hasil yang didapatkan termasuk dalam kriteria sedang. Berdasarkan hal ini kemampuan berpikir kreatif peserta didik tidak mengalami peningkatan yang sangat signifikan atau tidak terlalu signifikan. Meskipun angka pada nilai $\mathrm{N}$ gain yang ditunjukkan berbeda. Perbedaan nilai tersebut dapat dilihat pada Gambar 2.



Gambar 2 Grafik rata-rata N-Gain Kelas Eksperimen dan Kelas Kontrol

Setelah dilakukan perhitungan hasil nilai pretest dan posttest dari kelas eksperimen dan kelas kontrol, untuk membuktikan apakah pendekatan pembelajaran Socioscientific Issues berpengaruh terhadap kemampuan berpikir kretaif peserta didik, maka dilakukan uji statistik dari kedua kelas yaitu kelas eksperimen dan kontrol berupa uji normalitas, uji homogenitas dan uji hipotesis. Hasil analisis perhitungan statistik sebagai berikut. 
Tabel 2 Rekapitulasi Perhitungan Uji Normalitas perhitungan Data Tes Kemampuan Berpikir Kreatif.

\begin{tabular}{c|c|c|c|c}
\hline Uji Normalitas & Kelas & Kelompok & Hasil & Kriteria \\
\hline \multirow{2}{*}{$=\mathrm{X}^{2}=\frac{\sum(\text { (Oi }-E \mathrm{i})^{2}}{E_{\mathrm{i}}}$} & Eksperimen & $N$-gain & $\begin{array}{c}\chi^{2} \text { hitung }=5,1 \\
\chi^{2} \text { tabel } 0,95(3)= \\
7,81\end{array}$ & Berdistribusi Normal \\
\cline { 2 - 5 } & Kontrol & $N$-gain & $\begin{array}{c}\chi^{2} \text { hitung }=6,81 \\
\chi^{2} \text { tabel } 0,95(3)=7,81\end{array}$ & Berdistribusi Normal \\
\hline
\end{tabular}

Tabel 3 Rekapitulasi Perhitungan Uji Homogenitas Tes Kemampuan Berpikir Kreatif.

\begin{tabular}{c|c|c|c}
\hline Uji Homogenitas & Kelompok & Hasil & Kriteria \\
\hline$F=\frac{52 \text { Besar }}{s 2 \text { Kecil }}$ & N-Gain & $F(0,95) \frac{F_{\text {hitung }}=1,2}{a 1}=1,816$ & Varians Homogen \\
\hline
\end{tabular}

Tabel 4 Rekapitulasi Perhitungan Uji Hipotesis Penelitian

\begin{tabular}{c|c|c|c}
\hline Uji Hipotesis & $z_{\text {hitung }}$ & $z_{\text {tabel }}$ & Keterangan \\
\hline$Z=\frac{x_{1}-x_{2}}{\sqrt{\frac{x_{1}^{2}}{n 1}}+\sqrt{\frac{z_{2}^{2}}{n 2}}}$ & 3,177 & 1,998 & Berbeda Signifikan \\
\hline
\end{tabular}

Tabel 5 Nilai N-gain dan Selisih Setiap Indikator Berpikir Kreatif pada Kelas Eksperimen dan Kelas Kontrol

\begin{tabular}{lccccc}
\hline No & $\begin{array}{c}\text { Indikator Kemampuan } \\
\text { Berpikir Kreatif }\end{array}$ & Pretest & Postest & N-gain & Kriteria \\
\hline 1 & Kepekaan & 51 & 81 & 0.62 & Sedang \\
2 & Berpikir Lancar & 44 & 76 & 0.57 & Sedang \\
3 & Berpikir Luwes & 38 & 73 & 0.57 & Sedang \\
4 & Berpikir Keaslian & 37 & 70 & 0.53 & Sedang \\
5 & Berpikir Merinci & 32 & 71 & 0.58 & Sedang \\
\hline
\end{tabular}

Tabel 5 merupakan tabel rekapitulasi kemampuan berpikir kreatif yang menunjukkan ratarata nilai pretest dalam kemampuan berpikir kreatif dapat diketahui indikator kepekaan memiliki skor paling tinggi yaitu sebesar 51 dari nilai maksimal 100, sedangkan yang memiliki skor paling rendah terdapat pada indikator Berpikir Merinci yaitu sebesar 32. Dari hasil rata-rata posttest, setiap indikator mengalami peningkatan. Nilai $\mathrm{N}$-gain yang diperoleh menunjukkan bahwa adanya peningkatan kemampuan berpikir kreatif peserta didik. Meskipun semua indikakor menunjukkan peningkatan dan berkriterian sedang, namun indikator kepekaan dalam berpikir kreatif menunjukkan peningkatan yang paling tinggi yaitu dengan nilai $N$-gain 0,62. Indikator berpikir keaslian memiliki kriteria sedang namun menunjukkan nilai $N$-gain yang paling rendah yaitu dengan nilai 0,53 .
Penelitian yang dilakukan ini juga menggunakan data pendukung untuk mengetahui kemampuan berpikir kreatif peserta didik yaitu berupa angket tertutup dengan alternatif jawaban berupa sangat setuju, setuju, tidak setuju dan sangat tidak setuju. Pernyataan yang disajikan untuk peserta didik terdiri dari 10 pernyataan, ada pernyataan positif dan ada pula pertanyaan negatif. Data hasil anget ini digunakan untuk mengetahui bagaimana dan sejauhman tanggapan peserta didik terhadap pendekatan pembelajaran Socioscientific Issues pada materi pencemaran air. Indikator yang disajikan pada pertanyaan angket terdiri dari empat indikator yaitu (1) Ketertarikan dalam proses pembelajaran menggunakan pendekatan pembelajaran SSI; (2) Motivasi dalam mengikuti proses pembelajaran serta dalam berpikir kreatif; (3) Keaktifan peserta didik dalam proses pembelajaran dan (4) Pemahaman terhadap materi yang diajarkan. Angket respon 
peserta didik ini diberikan kepada peserta didik setelah melaksanakan kegiatan pembelajaran. Data hasil angket akan direkapitulasi kemudian diolah dalam bentuk persentase. Untuk memperjelas hasil tanggapan peserta didik terhadap pendekatan pembelajaran Socioscientific Issues dapat dilihat pada Gambar 4.5 dibawah ini.



Gambar 3 Grafik Rata-rata Persentase Jawaban Angket Peserta Didik Setiap Indikator.

Gambar 3 menunjukkan hasil rata-rata jawaban angket peserta didik indikator ketertarikan dalam proses pembelajaran menggunakan pendekatan pembelajaran SSI memiliki rata-rata persentase sebesar $84 \%$. Motivasi dalam mengikuti proses pembelajaran serta dalam berpikir kreatif menunjukkan nilai rata-rata persentase sebesar $79 \%$. Keaktifan peserta didik dalam proses pembelajaran menunjukkan nilai rata-rata persentase sebesar $80 \%$ dan Pemahaman terhadap materi yang diajarkan menunjukkan nilai rata-rata persentase sebesar $80 \%$.

Hasil penelitian menunjukkan secara umum kemampuan berpikir kreatif peserta didik baik kelas eksperimen dan kelas kontrol mengalami peningkatan. Kelas eksperimen dan kelas kontrol menunjukkan peningkatan karena nilai rata-rata posttes kelas eksperimen dan kelas kontrol lebih tinggi dibandingkan dengan nilai rata-rata pretest.
Pengaruh Pendekatan Pembelajaran Socioscientific Issues terhadap Kemampuan Berpikir Kreatif Peserta Didik

Dapat dilihat pada Tabel 6 peningkatan nilai rata-rata pretest kelas eksperimen lebih tinggi dibandingkan dengan dengan nilai rata-rata kelas kontrol. Nilai rata-rata pretest kelas eksperimen sebesar 40,6, sedangkan nilai rata-rata pada kelas kontrol sebesar 39,58. Apabila dilihat dari nilai posttest pun kelas eksperimen menunjukkan nilai ratarata yang lebih tinggi dibandingkan dengan kelas kontrol. Pada kelas eksperimen rata-rata nilai posttest yang dihasilkan sebesar 74,94, sedangkan pada kelas kontrol rata-rata nilai posttest yang dihasilkan yaitu sebesar 66,66.

Tabel 6 Rekapitulasi Nilai Pretest dan Posttest Kelas eksperimen dan kelas kontrol

\begin{tabular}{c|c|c|c|c}
\hline Kelas & Rata-rata Pretest & Rata-Rata Posttest & Rata-rata $\mathbf{N}$-gain & Kriteria \\
\hline Eksperimen & 40.6 & 74.94 & 0.56 & Sedang \\
\hline Kontrol & 39.58 & 66.66 & 0.44 & Sedang \\
\hline
\end{tabular}

Kelas ekperimen dan kelas kontrol menunjukkan kemampuan awal berpikir kreatif peserta didik yang berbeda. Berdasarkan hal tersebut maka dicari terlebih dahulu nilai $\mathrm{N}$-gain pada masing- masing kelas sampel. Setelah dilakukan perhitungan hasil yang didapatkan nilai $\mathrm{N}$-gain kelas eksperimen sebesar 0,56 sedangkan pada kelas kontrol nilai $N$ gain yang dihasilkan sebesar 0,44. Berdasarkan hasil 
tersebut kemampuan berpikir kreatif dengan menggunakan pendekatan pembelajaran Socioscientific Issues lebih unggul dibandingkan dengan kemampuan berpikir kreatif dengan model Direct Instuction.

Pendekatan Socioscientific Issues (SSI) adalah strategi yang bertujuan untuk menstimulasi perkembangan intelektual, moral dan etika, serta kesadaran prihal hubungan antara sains dengan kehidupan sosial (Zeidler, et. al., 2005 dan Nuangchalerm, 2010). Berdasarkan adanya stimulasi ini lah maka kemampuan berpikir kreatif peserta didik mengalami peningkatan.

Kreativitas adalah kegiatan yang mendatangkan hasil yang sifatnya baru, dan berguna. Baru dalam arti inovatif belum ada sebelumnya, menarik, mengejutkan dan berguna berarti lebih enak, lebih praktis, mempermudah, memperlancar, mendorong, mengembangkan, mendidik, memecahkan masalah, mengurangi hambatan, mengatasi kesulitan mendatangkan hasil lebih baik yang dikemukakan oleh David (dalam Putra, T. Tridaya. Dkk. 2012). Berdasarkan pengertian kreativitas di atas, sesuai dengan proses pembelajaran dengan menggunakan pendekatan pembelajaran SSI bahwa berpikir kreatif perlu dilatihkan pada peserta didik. Dengan dilatihkannya kemampuan berpikir kreatif pada peserta didik dapat mendorong, mendidik dan memicu peserta didik untuk dapat memecahkan masalah dengan gagasan yang dapat mengatasi kesulitan.

Peningkatan kemampuan berpikir kreatif peserta didik selama proses pembelajaran dengan pendekatan pembelajaran SSI juga dikemukakan oleh Callahan (2009) dan Zeidler et al. (2009) bahwa target kemampuan IImu Pengetahuan Alam (IPA) berbasis Socioscientific Issues SSI yang dapat dikembangkan adalah kemampuan berpikir kritis (critical thinking) dan berfikir kreatif (creative thinking) yang menunjukkan tingkat perkembangan interaksi seseorang dalam hal mengumpulkan dan menganalisis informasi atau data dari berbagai sumber. Kegiatan pembelajaran dengan menggunakan pendekatan pembelajaran Socioscientific Issues yang mengangkat isu-isu yang berada dilingkungan peserta didik dapat memicu peserta didik untuk menuangkan ide atau gagasan untuk memecahkan permasalahan yang timbul. Hal ini karena munculnya emosional peserta didik pada permasalahan sosial yang terjadi di lingkungan sekitarnya.

\section{Perbandingan Peningkatan Indikator Berpikir Kreatif antara pembelajaran Socioscientific Issues dengan Direct Instuction}

Indikator kemampuan berpikir kreatif yang digunakan pada penelitian ini yaitu kepekaan, berpikir lancaran, berpikir luwesan, berpikir keaslian dan berpikir merinci. Dari hasil penelitian yang dilakukan dengan menggunakan pendekatan pembelajaran Socioscientific Issues terhadap setiap peningkatan kemampuan berpikir kreatif peserta didik, maka peneliti akan membahas nilai hasil perhitungan setiap indikator berpikir kreatif.

\section{Indikator Kepekaan}

Indikator kepekaan merupakan indikator pada berpikir kreatif yang membentuk peserta didik untuk dapat memiliki kemampuan mendeteksi, mengenali dan memahami serta menanggapi suatu pernyataan, situasi atau masalah. Berdasarkan tabel 4.7 Indikator kepekaan pada kelas eksperimen memiliki nilai $N$-gain tertinggi dibandingkan dengan indikator berpikir kreatif yang lain dan lebih tinggi juga dibandingkan dengan hasil nilai $\mathrm{N}$-gain indikator kepekaan kelas kontrol. Indikator kepekaan kelas eksperimen menunjukkan nilai $\mathrm{N}$-gain sebesar 0,62 dengan kriteria sedang, sedangkan pada kelas kontrol menunjukkan nilai $\mathrm{N}$-gain sebesar 0,51 dengan kriteria sedang.

Indikator Berpikir Lancar

Indikator berpikir lancar merupakan indikator berpikir kreatif yang membentuk peserta didik untuk memiliki kemampuan menghasilkan banyak gagasan. Pada tabel 4.7 menunjukkan perbedaan hasil nilai $N$ gain pada kelas ekperimen dan kelas kontrol. Pada kelas ekperimen menunjukkan nilai $N$-gain sebesar 0,57 dengan kriteria sedang, sedangkan pada kelas kontrol menunjukkan nilai $N$-gain sebesar 0,42 dengan kriteria sedang. Berdasarkan hal ini kemampuan berpikir kreatif pada indikator berpikir lancar kelas eksperimen lebih tinggi dibandingkan dengan kelas kontrol.

\section{Indikator Berpikir Luwes}

Indikator berpikir luwes merupakan indikator berpikir kreatif yang membentuk peserta didik untuk memiliki kemampuan untuk mengemukakan bermacam-macam pemecahan atau pendekatan terhadap masalah. Pada tabel 4.7 menunjukkan nilai $N$-gain kelas ekperimen lebih tinggi dibandingkan dengan kelas kontrol. Nilai $\mathrm{N}$-gain pada kelas eksperimen sebesar 0,57 sedangkan pada kelas kontrol sebesar 0,46 . 
Indikator Berpikir Keaslian

Indikator berpikir keaslian merupakan indikator berpikir kreatif yeng membentuk peserta didik untuk memiliki kemampuan untuk mencetuskan gagasan dengan cara-cara yang asli, tidak klise dan jarang diberikan kebanyakan orang. Berdasarkan tabel 4.7 nilai $\mathrm{N}$-gain indikator berpikir keaslian menunjukkan nilai yang paling rendah baik pada kelas eksperimen dan kelas kontrol dibandingkan dengan indikator berpikir kreatif yang lain. Pada indikator berpikir keaslian nilai $\mathrm{N}$-gain kelas eksperimen lebih tinggi dibandingkan dengan kelas kontrol. Nilai N-gain pada kelas eksperimen sebesar 0,53 dengan kriteria sedang, sedangkan pada kelas kontrol sebesar 0,4 dengan kriteria sedang

\section{Indikator Berpikir Merinci}

Indikator berpikir merinci pada berpikir kreatif membentuk peserta didik untuk memiliki kemampuan menambah suatu situasi atau masalah, sehingga menjadi lengkap dan memerincinya secara detail yang di dalam nya terdapat tabel, grafik, gambar dan katakata. Pada tabel 4.7 menunjukkan bahwa nilai $\mathrm{N}$-gain kelas ekperimen lebih tinggi dibandingkan dengan nilai $N$-gain kelas kontrol. Nilai $N$-gain kelas eksperimen sebesar 0,58 berkriteria sedang, sedangkan pada kelas kontrol sebesar 0,44.

Zeidler dkk (2005) mengemukakan bahwa pembelajaran dengan pendekatan Socioscintific Issues tidak hanya mengembangkan kemampuan berpikir kritis saja, tetapi juga kemampuan lainnya pun dapat dikembangkan seperti kemampuan berpikir kreatif, kemampuan mengambil keputusan dan kemampun berargumentasi. Manfaat dari pembelajaran menggunakan pendekatan pembelajaran Socioscientific Issues dapat memudahkan peserta didik dalam mengeksplorasi pengetahuan karena isu yang disajikan dekat dengan kehidupan peserta didik.

Perbedaan situasi kelas pada kelas kontrol dan model pembelajran yang bersifat teacher-centre menjadikan kemampuan berpikir kreatif peserta didik lebih rendah. Pada kelas kontrol pengetahuan yang dipelajari sangat bergantung pada guru, hal ini diakibatkan kecenderungan peserta didik bersifat lebih pasif dan tidak mandiri dalam proses pembelajaran. Hal ini pun berpengaruh pada situasi di dalam kelas, dimana ketertarikan peserta didik dalam proses pembelajaran menjadi rendah, sehingga tujuan pembelajran pun sulit untuk dicapai. Selain itu juga berpengaruh pada peningkatan setiap indikator kemampuan berpikir kreatif peserta didik. Dapat dilihat pada Tabel 4.7, meskipun nilai $N$-gain kelas kontrol menunjukkan kriteria sedang, tetapi angka yang ditunjukkan lebih rendah dibandingkan dengan nilai $N$-gain kelas eksperiemen. Ini menandakan bahwa kemampun berpikir kreatif kelas eksperimen lebih tinggi dibandingkan dengan kelas kontrol.

\section{Tanggapan serta Respon Peserta Didik terhadap Pendekatan Pembelajaran Socioscientific Issues}

Angket tanggapan serta respon peserta didik terhadap pendekatan pembelajaran Socioscientific Issues diberikan kepada peserta didik setelah mengikuti kegiatan proses pembelajaran selesai dilaksanakan. Tujuan pemberian angket ini untuk melihat respon dan tanggapan peserta didik setelah mengikuti kegiatan proses pembelajaran dengan menggunakan pendekatan Pemebelajaran Socioscientific Issues. Ada empat aspek pada angket yang diberikan kepada peserta didik yaitu ketertarikan peserta didik terhadap pendekatan pembelajaran Socioscientific Issues, motivasi dalam mengikuti proses pembelajaran serta dalam berpikir kreatif, keaktifan peserta didik dalam pembelajaran dan pemahaman materi yang telah diajarkan.

Berdasarkan hasil yang diperoleh secara keseluruhan, tanggapan dan respon peserta didik terhadap pendekatan pembelajaran Socioscientific Issues termasuk kedalam sanagat setuju berdasarkan Sugiono (2016). Hasil ini mendukung analisis data yang diperoleh bahwa terdapat pengaruh pendekatan pembelajaaran Socioscientific Issues terhadap kemampuan berpikir kreatif peserta didik.

\section{KESIMPULAN}

Berdasarkan pengolahan data hasil penelitian diperoleh bahwa pendekatan pembelajaran Socioscientific Issues berpengaruh terhadap kemampuan berpikir kreatif pesert didik pada materi pencemaran Air. Hasil uji z menunjukkan bahwa data yang dihasilkan sesuai dengan kriteria yaitu $\mathrm{z}_{\text {hitung }}=$ $3,177>z_{\text {tabel }}=1.998$ dengan tingkat kepercayaan 0,05 (5\%), artinya pendekatan pembelajaran Socioscientific Issues berpengaruh terhadap kemampuan berpikir kreatif peserta didik pada materi pencemaran air. Hasil setiap indikator pada indikator berpikir kreatif mengalami peningkatan.

Adapun tanggapan peserta didik terhadap penerapan pendekatan pembelajaran Socisoscientific Issues secara keseluruhan termasuk kedalam kriteria sangat setuju. Hasil ini menunjukkan bahwa peserta didik tertarik, termotivasi, lebih aktif dan lebih paham dalam mengikuti kegiatan pembelajaran dengan 


\section{DAFTAR PUTAKA}

Callahan, Brendan E, (2019), Nhancing Nature of Science Understanding, Reflective Judgement, and Argumentation Through Socioscientific Issues, Dissertation, University of South Folandia, http://scholarcommons,usf,edu/etd/1886/pdf, (diakses pada Mei 2018).

Meltzer, D,E, (2002), The Relationship Between Mathematics Preparation and Conceptual Learning Grains in Physics: A Possible "Hidden Variable" in Diagnostics Pretest Scores, American Journal Physics, Vol 70 (12), :27.

Partnership for 21st century Skill, (2002), Learning for the 21st century, A Report and MILE Guide for 21st century skills, www,21stcenturyskills,org,P21,Report,pdf (diakses 20 September 2017).

Putra, Tomi Tridaya, (2012), Meningkatkan Kemampuan Berpikir Kreatif Siswa Dengan Pembelajaran Berbasis Masalah, Jurnal Pendidikan Matematika, Part 3, Vol, 1 (1): 22-26.

Sugiono, (2016), Metode Penelitian Pendidikan,Bandung, Alfabeta.

Suparman \& Dwi Nastuti Husen, 2015, Peningkatan Kemampuan Berpikir Kreatif Siswa Melalui Penerapan Model Problem Based Learning, Jurnal Bioedukasi, Vol 3 No (2): 2301-4678.

Tekin, E, Nurcan, et,al, (2016), Research Trends on Socioscientific Issues: A Content Analysis of Publications in Selected Science Education Journals, Journal of Education and Training Studies, Vol, 4 (9): 16-24.

Zeidler, D,L,,et al, (2005), Beyond STS: AResearchBased Framework fof Socioscientific Issues Education, Jurnal of Science Education, Vol 89 (3): 357-377. 